\title{
KEPUASAN REMAJA TERHADAP PENGGUNAAN MEDIA SOSIAL INSTRAGRAM DAN PATH
}

\author{
Gusmia Arianti \\ Program Studi Ilmu Komunikasi Universitas Al Azhar Indonesia (UAI) \\ gusmia.arianti@uai.ac.id
}

Diajukan: 24-10-2017; Direview: 01-11-2017; Diterima: 05-12-2017;

\begin{abstract}
Development of information technology has resulted in the widespread of information. One of the mostacknowledged proof of it is the emergence of new media. Most of people's activity are inseparable with the internet. Some of the most widely used social media today are Path and Instagram. This research aims to analyze the phenomenon of social media use the focus of this research are as follows the social media credibility to fulfill the information need of society and to answer the problem about the actualization of used and gratification theory the use of path and instagram. The atributes of statisfaction of the use of social media Path and Instagram are nomely for social interactioninformation seeking, pass time, entertainment, relaxation, communicatory utility, convenience utility. The highert level of satisfaction of social media user happened to be collage student Instagram user. It means that collage student feel most satisfied with the features that Instagram has. Generally, young people feel satisfied by using Instagram rather than using Path.
\end{abstract}

Keyword: Social media, uses and gratification theory, satisfaction

\begin{abstract}
Abstrak
Semakin berkembangnya teknologi informasi mengakibatkan penyebaran informasi menjadi semakin berkembang, salah satunya dengan munculnya media baru. Sebagian besar aktivitas kehidupan masyarakat tidak dapat dipisahkan dengan internet. Media sosial yang banyak digunakan saat ini adalah Instagram dan Path. Penelitian ini bertujuan menganalisis fenomena penggunaan media sosial dengan fokus kajian pada kredibilitas media sosial untuk memenuhi kebutuhan informasi masyarakat dan menjawab persoalan tentang aktualisasi uses and gratification theory, khususnya penggunaan media sosial Instagram dan Path. Atribut-atribut kepuasan penggunaan media sosial Instagram dan Path yang digunakan adalah untuk interaksi sosial, mencari informasi, menghabiskan waktu, hiburan, relaksasi, kegunaan berkomunikasi dan kenyamanan. Tingkat kepuasan pengguna media sosial yang paling tinggi adalah pengguna Instagram di kalangan Mahasiswa, artinya kalangan mahasiswa merasa sangat puas dengan fitur dan kelebihan yang dimiliki oleh Instagram. Secara umum, remaja merasa puas dengan menggunakan Instagram dibandingkan dengan Path.
\end{abstract}

Kata Kunci: Media sosial, teori uses and gratification, kepuasan

\section{PENDAHULUAN}

$\mathrm{M}$ edia dan komunikasi merupakan dua hal yang penting dalam hal menyebarkan dan menyalurkan informasi.Dalam kehidupan sebagian besar orang menghabiskan waktunya di depan TV, mendengarkan musik di mobil, membaca koran, majalah ataupun buku.
Kondisi ini memberikan gambaran bahwa orang/ individu/masyarakat menghabiskan waktunya untuk 'mengkonsumsi' beragam bentuk media. Semakin berkembangnya teknologi informasi mengakibatkan penyebaran informasi menjadi semakin berkembang, salah satunya dengan munculnya media baru. Sebagian besar aktivitas 
kehidupan masyarakat tidak dapat dipisahkan dengan internet. Penggunaan media baru dalam setiap lini kehidupan memudahkan masyatakat untuk menerima dan menyebarkan informasi dengan cepat.

Jumlah pengguna Internet di Indonesia kini terus bertambah. Data Badan Pusat Statistik pada 2011-2015 tercatat untuk kelompok usia 2564 tahun, 79,02 persen pengakses internet berada di perkotaan dan hanya 20,98 persen penduduk pedesaan yang gemar berselancar dalam jaringan (daring). Adapun pembagian berdasarkan jenis kelamin para akses internet tahun 2015 adalah 59,08 persen laki-laki dan 40,92 persen perempuan. Khusus wilayah perkotaan jumlah data terpilah penduduk usia 25-64 tahun yang berinternet ialah 22,87 persen perempuan dan 31,37 persen lakilaki. Umumnya warga mengakses internet dari telephone pintar (Kompas, 6 Desember 2016, Hatihati Mengunggah Konten di Media Sosial,oleh DNE ;Kompas12 Juni 2017, Pengguna Awam Rentan, oleh ELD)

Data lainnya menunjukkan pada Maret 2017 saja penetrasi internet di Indonesia sudah mencapai 50,4 persendari total populasi atau mencapai 132,7 juta pengguna internet. Statista. com memprediksi, pada 2021, pengguna internet di Indonesia setidaknya akan mencapai 144,2 juta. Semakin banyak penduduk terhubung internet, semakin besar peluang untuk mendorong keterlibatan warga dalam aktivitas kewargaan di dunia maya. Data lain juga menunjukkan bahwa 83 persen pengguna internet ada di pulau Jawa (Membaca Indonesia, Dunia Maya dan Demokrasi Deliberatif, Kompas, 7 Juni 2017, oleh Agnes Theodora dan Anthonu Lee; Kompas, 9 Januari

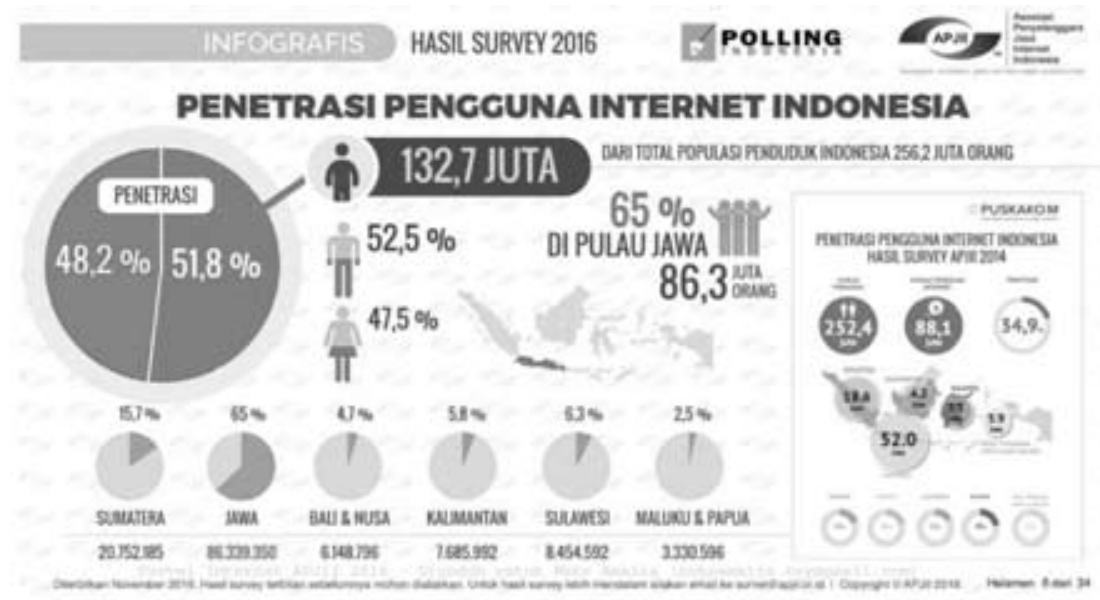

Gambar 1. Infografis Penetrasi dan Perilaku Pengguna Internet di Indonesia. Sumber: Asosiasi Penyelenggara Jasa Internet Indonesia (APJII) 2016

2017, Hoax mengancam persatuan Bangsa).

Perkembangan media baru di Indonesia mengalami peningkatan yang sangat pesat, berdasarkan hasil survei internetAsosiasi Penyelenggara Jasa Internet Indonesia (APJII) tahun 2016 tentang penetrasi pengguna internet di Indonesia, jumlah total pengguna internet Indonesia saat ini sudah mencapai 132.7 juta pengguna. Jumlah tersebut meningkat signifikan dibandingkan hasil survei 2014 yang mencapai 88 juta.

Survei yang dilakukan APJII menjabarkan karakteristik pengguna di Indonesia digolongkan berdasarkan usia. Pengguna internet di Indonesia berusia 35-44 tahun memperoleh persentase lebih besar yaitu 29.2 persen dari total pengguna intenet, diikuti dengan pengguna usia 25-34 sebesar 24.4 persen, usia 10-24 sebesar 18.4 persen, lalu 45-54 tahun sebesar 18 persen, dan terakhir usia 56-65 sebesar 10 persen. Sedangkan bila digolongkan dari pekerjaan, setengah dari pengguna internet di Indonesia dengan persentase 62 persen merupakan golongan pekerja / wiraswasta, diikuti oleh profesi ibu rumah tangga dengan persentase 16.6 persen, lalu mahasiswa sebesar 7.8 persen dan pelajar 
6.3 persen. Hal ini menunjukkan bahwa remaja merupakan konsumen potensial pengguna internet di Indonesia.

Penetrasi pengguna internet ini membuktikan bahwa sebagian besar media yang digunakan masyarakat untuk melakukan komunikasi adalah dengan menggunakan internet. Salah satu media yang dapat digunakan dengan memanfaatkan fasilitas internet adalah media sosial. Media sosial mengacu pada penggunaan teknologi berbasis web dan mobile yang berguna untuk mengubah komunikasi ke dalam bentuk dialog yang interaktif. Media sosial merupakan sebuah media online, yang memungkinkan para penggunanya untuk dapat berkomunikasi serta berinteraksi satu sama lain tanpa batas. Dengan media sosial, informasi dapat diperoleh dengan cepat.

Iklim kompetitif media massa semakin terasa dengan kehadiran media online, menciptakan persaingan antar media dalam jumlah dan ragam yang hampir tidak terbatas. Media online yang tetap eksis dan mendapatkan rating pengunjung adalah media online yang memiliki kredibilitas tinggi dimata pengguna (Siswanta 2015: 211-212).

Media sosial bisa digunakan untuk berbagai hal, bertukar informasi, menampilkan foto atau video yang dimiliki pengguna, atau bahkan bisa juga digunakan untuk berbisnis / mempromosikan suatu produk. Kehadiran media sosial dapat membuat setiap orang berkontribusi menjadi komunikator, karena setiap individu bisa menyampaikan suatu informasi yang mereka alami dan mereka lihat sesuai dengan keinginan mereka.Media sosial mampu mengubah pola distiribusi informasi karena memungkinkan seseorang melakukan percakapan tanpa dihambat oleh ruang. Sifat unik media sosial mempunyai potensi untuk mengubah cara manusia berinteraksi. Hanya saja membutuhkan waktu untuk membuat seseorang terpuaskan dengan menggunakan media sosial (Gilles, 2003: 23). Perubahan pola perilaku masyarakat dalam proses komunikasi banyak disoroti dengan menggunakan

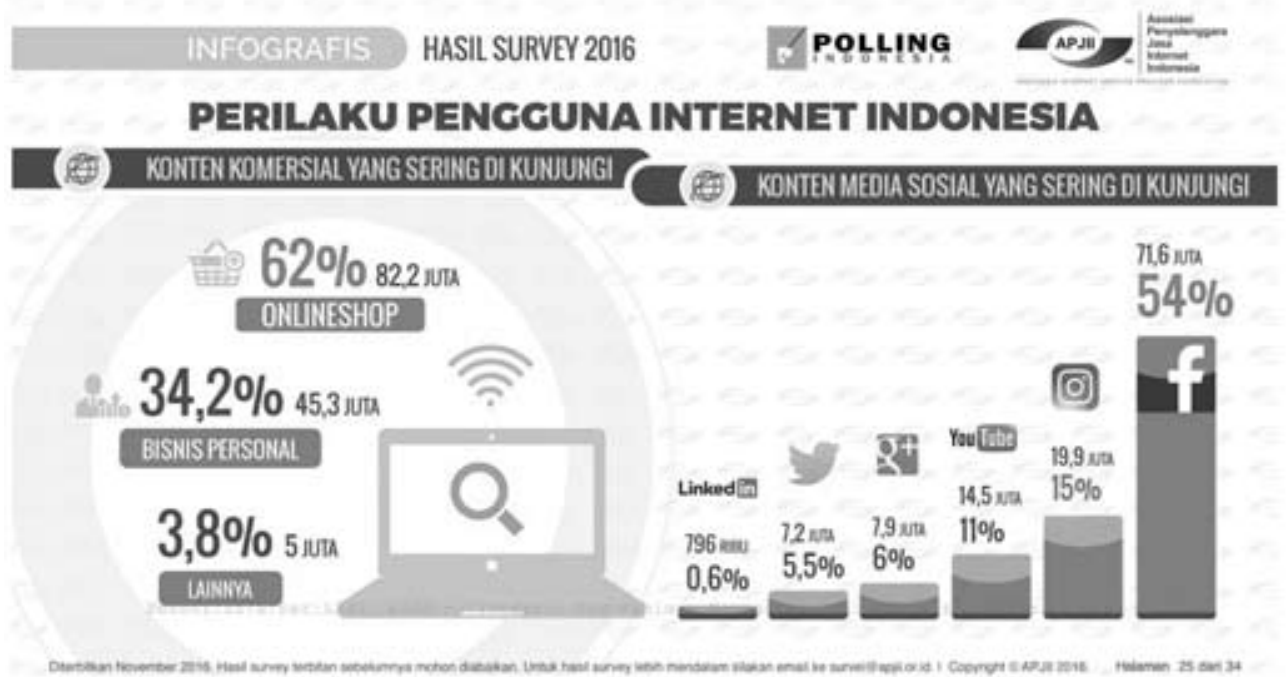

Gambar 2. Konten media sosial yang sering di kunjungi.

Sumber: Asosiasi Penyelenggara Jasa Internet Indonesia (APJII) 2016

teori Uses and gratification. Teori ini memberikan jawaban atas persoalan apa yang dilakukan masyarakat terhadap eksistensi media massa dalam upaya pemenuhan kebutuhan informasi mereka (Siswanta 2015: 211-2014). Effendi (2003:407) menambahkan bahwa yang menjadi persoalan utama penelitian komunikasi pada massa bukanlah bagaimana mengubah sikap dan perilaku khalayak, tetapi bagaimana media massa memenuhi kebutuhan pribadi dan sosial khalayak.

Jenis media sosial yang sudah berkembang saat ini, antara lain Facebook, Twitter, Instagram, Path, dan YouTube. Instagramadalah sebuah aplikasi media sosial yang memberikan cara cepat dan menyenangkan untuk berbagi media melalui konten platform tertentu, yaitu snap foto, memilih 
filter-filter untuk mengubah tampilan dan nuansa foto, serta dapat menambahkan komentar dalam posting foto tersebut.

Instagram merupakan media sosial yang terbilang masih baru dibandingkan media-media sosial lainnya seperti Facebook, Twitter, dan lainnya. Survey yang dilakuakan oleh APJII (2016), Instagram merupakan media sosial kedua yang sering di kunjungi setelah Facebook. Menurut data dari MAU (Monthly Active Users) jumlah pengguna aktif Instagram di Indonesia saat ini sudah mencapai 22 Juta pengguna.Bahkan menurut survey Jakpat, Instagram saat ini lebih popular dibandingkan dengan Twitter di Indonesia, khususnya di kalangan remaja. Pengguna Instagram di Indonesia mayoritas menggunakan layanan ini untuk mencari informasi produk online shop,meme, dan mengunggah foto-foto liburan dan wisata (https://dailysocial.id/post/penggunaaktif-instagram-di-indonesia-capai-22-juta).

Tulisan ini akan menganalisis fenomena penggunaan media sosial dengan fokus kajian pada kredibilitas media sosial untuk memenuhi kebutuhan informasi masyarakat dan menjawab persoalan tentang aktualisasi uses and gratification theory, khususnya penggunaan media sosial Instagram dan Path. Penelitian ini bertujuan untuk menganalisis perbedaan kepuasan remaja terhadap penggunaan media sosial Instagram dan Path.

\section{LITERATUR DAN METODOLOGI \\ Teori Uses and Gratification}

Model uses and gratification merupakan pergeseran fokus dari tujuan komunikator kepada tujuan komunikan. Model ini menentukan fungsi komunikasi massa dalam melayani khalayak. Pendekatan uses and gratifications untuk pertama kali dijelaskan oleh Katz (1959) yang dikutip West dan Turner (2007) menunjukkan kebanyakan penelitian komunikasi sampai waktu itu diarahkan kepada penyelidikan efek kampanye persuasi pada khalayak. Katz mengatakan bahwa penelitiannya diarahkan kepada jawaban terhadap pertanyaan what do the media do to people (Apa yang dilakukan media untuk khalayak?) (Effendy 2003: 289). Penelitian dilakukan untuk mengetahui apa yang terjadi dibalik penggunaan media oleh audien atau mencari tahu mengapa orang memilih media tertentu dan memberikan perhatian terhadap efek langsung suatu media bukan media lainnya (Morrisan et al 2010).

Peneliti uses and gratification melihat adanya motivasi penggunaan media dan kebutuhan atas manfaat dari media.Tipe subjek uses and gratification adalah orang dewasa yang terisolasi menggunakan media untuk menemani dan memerlukan informasi dari dunia luar. Pengguna media menjadi bagian yang aktif dalam proses komunikasi yang terjadi serta berorientasi pada tujuannya dalam media yang digunakannya (Miller, 2002; Giles, 2003: 23-25).

Ide teori uses and garitification berangkat dari teori expectancy-value Martin Fishbein pada tahun 1984, yang menyatakan bahwa formula dalam menentukankepuasanyang akandicarioleh penggunamedia denganmenjumlahkankeyakinan mereka tentangapa yang media memberikan tertimbang oleh evaluasi dari keyakinan seseorang (Littlejohn dan Foss 2009). Teori ini diterapkan oleh Ajzen dan Fisbeinyaitu teori reason action (alasan suatu aksi) untuk mengkaji penggunaan media dan sikap terhadap media (Giles 2003:24). Teori uses and gratification sering dinilai sebagai gagasan yang memandang media memberikan efek terbatas pada audien, dengan kata ini teori ini menjamin kemampuan individu untuk melakukan kontrol terhadap media yang mereka konsumsi karena mereka memiliki kemampuan terbatas untuk mempengaruhi audien.

Teori uses and gratifications menunjukan bahwa yang menjadi permasalahan utama bukanlah bagaimana media mengubah sikap dan perilaku khalayak, tetapi bagaimana media memenuhi kebutuhan pribadi dan sosial khalayak (Littlejohn dan Foss 2009). Pendekatan uses and gratificationsmerupakan pergeseran paradigma dari khalayak pasif ke arah khalayak aktif artinya perspektif ini lebih melihat apa yang dilakukan individu terhadap media daripada perlakuan media terhadap individu, individu sebagai entitas aktif memiliki kebebasan tidak saja dalam memilih jenis tetapi juga isi media yang dikonsumsinya.

Katz, Blumer, dan Gurevitch (1974)yang dikutip Rakhmat (1999) mengemukakan bahwa 
konsep uses and gratifications yang diteliti ialah:sumber sosial dan psikologis, darikebutuhan yang melahirkan harapan-harapan,darimedia massa atau sumber-sumber yang lain, yang menyebabkanperbedaan pola terpaan media (atau keterlibatan dalam kegiatan lain), dan menghasilkan (pemenuhan kebutuhan dan akbatatakibat lain, bahkan sering kali akibat-akibat yang tidak dikehendaki).

Teori uses and gratification memberikan sebuah kerangka untuk memahami kapan dan bagaimana konsumen media individu menjadi lebih atau kurang aktif dan konsekuensi dari keterlibatan yang meningkat dan menurun. Asumsi Teori uses and gratifications menurut Katz, Blumler \& Gurvitch (1974) yang dikutip oleh West dan Turner (2007): 1) Khalayak aktif dan penggunaan medianya berorientasi pada tujuan; 2) Intensif dalam menghubungkan kepuasan kebutuhan pada pilihan media tertentu terdapat pada anggota khalayak; 3) Media berkompetisi dengan sumber lainnya untuk kepuasan kebutuhan; 4) Orang mempunyai cukup kesadaran diri akan pengunaan media mereka, minat dan motif sehingga dapat memberikan sebuah gambaran yang akurat mengenai kegunaan tersebut kepada para ahli; 5) Penilaian mengenai nilai isi media hanya dapat dinilai oleh khalayak.

Model ini memulai dengan lingkungan sosial (social enviroment) yang menentukan kebutuhan kita. Lingkungan sosial tersebut meliputi ciri-ciri afiliasi kelompok dan ciri-ciri kepribadian. Kebutuhan individual (individual's need) dikategorisasikan sebagai; Pertama cognitive need(kebutuhan kognitif): kebutuhan yang berkaitan dengan peneguhan informasi, pengetahuan dan pemahaman mengenai lingkungan. Kebutuhan ini didasarkan pada hasrat untuk memahami dan menguasai lingkungan; juga memuaskan rasa penasaran kita dan dorong untuk penyelidikan kita. Kedua, affective need (kebutuhan afektif): kebutuhan yang berkaitan dengan peneguhan pengalaman-pengalaman yang estetis, menyenangkan, dan emosional. Ketiga, personal integrative need(kebutuhan pribadi secara integratif): kebutuhan berkaitan dengan peneguhan kredibilitas, kepercayaan, stabilitas, dan status individual. Hal-hal tersebut diperoleh dari hasrat akan harga diri. Keempat, social integrative need(kebutuhan sosial secara integratif): kebutuhan yang berkaitan dengan peneguhan kontak dengan keluarga, teman, dan dunia. Hal-hal tersebut didasarkan pada hasrat untuk berafiliasi. Dankelima, (kebutuhan pelepasan): kebutuhan yang berkaitan dengan upaya menghindarkan tekanan, ketegangan, dan hasrat akan keanekaragamanescapist need (West dan Turner 2007; Effendy, 2003: 294).

Salah saturiset Uses and Gratifications yang saat ini berkembang adalah tidak hanyamemfokuskan pada motif sebagai variabel independen yang sama yaitu orang menggunakan media didorong oleh motif-motif tertentu, namun dengan menanyakan apakah motif-motif khalayak itu telah dapat dipenuhi oleh media. Dengan kata lain, apakah khalayak puas setelah menggunakan media. Konsep mengukur kepuasan ini disebut Gratification Sought (GS) dan Gratification Obtained (GO). GS (Gratification Sought) adalah kepuasan yang dicari atau diinginkan ketika mengkonsumsi suatu jenis media tertentu. Sedangkan GO (Gratification Obtained) adalah kepuasan yang nyata yang diperoleh seseorang setelah mengkonsumsi suatu jenis media tertentu (Palmgreen 1985 yang dikutip Kriyantono 2010).

\section{Social Media}

Menurut Kaplan and Haenlein (2010: 60) social media merupakan sebuah kelompok aplikasi berbasis internet yang membangun di atas dasar ideologi dan teknologi Web 2.0, dan memungkinkan penciptaan dan pertukaran user-generated content, serta telah mengubah kehidupan individu maupun perusahaan pada 1 dekade lalu.

Faktanya, media sosial telah menjadi bagian yang sangat penting dalam kehidupan seharihari. Dengan meningkatnya ketersediaan akses internet berkecepatan tinggi, lebih lanjut menambahkan popularitas konsep, menuju penciptaan situs jejaring sosial seperti MySpace (2003) dan Facebook (2004). Meskipun daftar aplikasi-aplikasi ini dapat memberikan beberapa gagasan tentang pengertian media sosial, namun definisi resmi untuk istilah pertama membutuhkan hubungan dua konsep yang terkait dengan media 
sosial, yaitu Web 2.0 dan User Generated Content. Web 2.0 merupakan istilah yang digunakan pada tahun 2004 untuk menggambarkan cara baru dalam mengembangkan software dan end-user yang mulai memanfaatkan World Wide Web (www) sebagai platform dimana konten dan aplikasi tak lagi dibuat dan dipublikasikan oleh individu, melainkan dikombinasikan oleh semua pengguna. Sedangkan User Generated Content (UGC) dapat dilihat sebagai jumlah dari semua cara dimana orang-orang memanfaatkan media sosial. Menurut Organization for Economic Cooperation and Development (OEDC, 2007), UGC mempunyai kebutuhan untuk memenuhi 3 persyaratan dasar untuk beberapa pertimbangan: Pertama, perlu dipublikasikan baik pada sebuah web yang dapat diakses publik atau pada situs jejaring sosial yang bisa diakses sekelompok orang; kedua, perlu menunjukkan sejumlah usaha kreatif; dan ketiga, perlu membuat sesuatu diluar rutinitas yang professional dan praktek.

\section{Metodologi}

Penelitian ini menggunakan metode kuantitatif. Metode penelitian kuantitatifadalah jenis penelitian yang menghasilkan penemuan-penemuan yang dapat dicapai atau diperoleh dengan menggunakan prosedur-prosedur statistik atau cara-cara lain dari kualifikasi pengukuran.Pendekatan ini digunakan untuk meneliti masalah yang bersifat kuantitas (Sugiyono, 2009).

Sumber data diperoleh melalui data primer dan data sekunder. Sumber primer merupakan sumber data yang langsung diperoleh dari pengumpulan data. Pengumpulan data dilakukan dengan menggunakan instrumen kuesioner yang diberikan kepada responden. Data sekunder diperoleh melalui studi pustaka.

Penelitian ini dilakukan di wilayah DKI Jakarta pada bulan Maret-April 2017. Populasi dalam penelitian ini adalah remaja usia 18-22 tahun dengan asumsi remaja pada usia Sekolah Menengah Atas (SMA) dan mahasiswa. Jumlah responden yang diambil sebagai sampel ditentukan dengan menggunakan rumus Slovin (Umar 2004). Dengan error 10 persen maka sampel yang dianggap memadai berjumlah 98 orang dan pada penelitian ini sampel yang digunakan adalah sebanyak 150 orang dengan perbandingan proporsional antara siswa SMA (75 orang) dan mahasiswa (75 orang) sehingga jumlah tersebut dianggap representatif.Metode penarikan sampel dilakukan denganConvenience Sampling yang merupakan bagian dari non-probability sampling. Convenience sampling adalah teknik penentuan sampel berdasarkan kebetulan, yaitu siapa saja yang secara kebetulan bertemu dengan peneliti dapat digunakan sebagai sampel, bila dipandang orang yang kebetulan ditemui itu cocok sebagai sumber data (Sumarwan\& Efendi 2011). Syarat responden yang terpilih mempunyai sifat yaitu pengguna aktif media sosial Instagram dan Path minimal enam bulan terakhir dan mengakses setiap minggu.

Pertanyaan kuesioner divalidasi dengan menggunakan analisis butir. Analisis butir menurut Suliyanto (2005) dilakukan dengan cara mengkorelasikan skor item dengan skor total itemnya. Skor item dianggap sebagai nilai $\mathrm{X}$ sedangkan skor total dianggap sebagai nilai Y. Sedangkan uji reliabilitas menggunakan metode Alpha (Cronbach's).

Hasil pengujian tingkat validitas menunjukan bahwa $r$ hitung atribut dalam pertanyaan tersebut memiliki nilai korelasi antara 0.451 sampai dengan 0.801 dan tidak ada yang lebih kecil dari $r$ tabel 0.367 . Hal ini menunjukan bahwa pertanyaan dalam kuesioner dinyatakan valid. Berdasarkan hasil pengujian reliabilitas menunjukan bahwa nilai alpha sebesar 0.90 dan 0.83 . Nilai alpha tersebut lebih dari 0.60 , hal ini menunjukan bahwa atribut-atribut tersebut adalah reliable.

Selanjutnya data diolah dengan menggunakan metode IPA-CSI dengan memberikan pertanyaan seberapa besar harapan suatu atribut terntentu dan seberapa besar yang mereka rasakan (Rangkuti 2003). Analisis IPA (Importance Performance Analysis) dan CSI (Customer Satisfaction Index) digunakan untuk mengetahui atribut-atribut yang menjadi tingkat kepentingan dan kinerja produk dan tingkat kepuasan pengguna. Pada metode ini, responden diminta untuk menilai tingkat kepentingan berbagai atribut yang relevan dan tingkat kinerja media sosial (perceived 
performance) pada masing-masing atribut. Matriks ini sangat bermanfaat sebagai pedoman dalam mengaplikasikan sumber daya organisasi yang terbatas pada bidang-bidang spesifik, dimana perbaikan kinerja bisa berdampak besar pada kepuasan total konsumen. Selain itu, matriks ini juga menunjukan bidang atau atribut tertentu yang perlu dipertahankan dan aspek-aspek yang perlu dikurangi prioritasnya (Martila \& James yang dikutip Sumarwanet al. 2011). Tahapan-tahapan pengukuran CSI adalah sebagai berikut: Pertaman, menghitung Weighting Factor (WF), yaitu mengubah nilai rata-rata kepentingan menjadi angka persentase dari total rata-rata tingkat kepentingan seluruh atribut yang diuji, sehingga didapatkan total WF sebesar 100\%. Kedua, menghitung Weight Score (WS), yaitu menilai perkalian antara nilai rata-rata tingkat kepuasan masing-masing atribut dengan WF masing-masing atribut. Ketiga, menghitung Weight Total (WT), yaitu menjumlahkan WS dari semua atribut.

Menghitung Satisfaction Index, yaitu WT dibagi skala maksimum yang digunakan, kemudian dikalikan 100\%. Tingkat kepuasan responden secara keseluruhan dapat dilihat dari kriteria tingkat kepuasan.Kriteriakepuasan yang digunakan adalah:

$$
\begin{aligned}
& 0 \%<\mathrm{CSI} \leq 20,0 \%=\text { sangat tidak puas } \\
& 20,1 \%<\mathrm{CSI} \leq 40,0 \%=\text { tidak puas } \\
& 40,1 \%<\mathrm{CSI} \leq 60,0 \%=\text { kurang puas } \\
& 60,1 \%<\mathrm{CSI} \leq 80,0 \%=\text { puas } \\
& 80,1 \%<\mathrm{CSI} \leq 100 \%=\text { sangat puas }
\end{aligned}
$$

\section{TEMUAN DAN DISKUSI}

\section{Analisis Kepuasan Pengguna (Importance Performance Analysis)}

Importance Performance Analysis (IPA) merupakan alat yang dapat digunakan untuk menghitung tingkat kepentingan dan tingkat kinerja atribut. Pengukuran kepuasan pengguna media sosial dengan metode ini dapat memberikan gambaran tentang atribut yang harus dipertahankan, ditingkatkan dan berlebihan. Hasil penggabungan kepentingan dan kinerja dibagi dalam empat kuadran sebagai indikator kepuasan pengguna secara keseluruhan. Penentuan posisi atribut penelitian yang berjumlah 20 tersebut ditentukan berdasarkan nilai rata-rata baik tingkat kepentingan maupun tingkat kinerja masingmasing (Rangkuti, 2003): Kuadran I (Attributes to Improve): Prioritas utama.Atribut- atribut yang dianggap penting oleh konsumen, tetapi pada kenyataannya atribut-atribut ini belum sesuai dengan harapan. Tingkat kepuasan pengguna pada kuadran ini masih rendah sehingga perusahaan perlu mengingkatakan kinerja dari atribut-atribut tersebut.Kuadran II (Maintain Performance): Pertahankan prestasi.Atribut-atribut yang dianggap penting telah sesuai dengan kenyataan yang dirasakan oleh pengguna, sehingga tingkat kepuasan relatif tinggi.Atribut-atribut yang masuk ke dalam kuadran ini harus tetap dipertahankan. Kuadran III (Attributes to Maintain): Prioritas rendah, pada kondisi ini ditunjukan atribut-atribut yang kurang penting pengaruhnya bagi pengguna dimana pelaksanaannya tidak terlalu baik. Peningkatan variabel perlu diperhatikan kembali karena pengaruhnya yang tidak terlalu besar terhadap kepuasan pengguna.Kuadran IV (Main Priority): Berlebihan, pada kondisi ini memuat atribut-atribut yang dianggap kurang penting dan kinerjanya dinilai berlebihan.

Menurut Innova(2016) Kebutuhanmanusia yang dapat dipuaskan melalui media, yang terdiri dari: 1) interaksi sosial (social interaction)didefinisikan bahwa menggunakan sosial media untuk berkomunikasi dan berinteraksi dengan orang lain (Ko et al, 2005: 2) mencari informasi (information seeking) didefinisikan bahwa menggunakan media sosial untuk mencari informasi atau untuk mendidik diri sendiri (Papacharissi \& Rubin penelitian, 2000: 3) menghabiskan waktu (pass time) didefinisikan bahwa menggunakan media sosial untuk mengisi waktu dan menghilangkan kebosanan (Palmgreen \& Rayburn's, 1979); 4) hiburan (entertainment) didefinisikan bahwa menggunakan media sosial untuk memberikan hiburan dan rekreasi (Palmgreen \& Rayburn (1979), Papacharissi \& Rubin, 2000: 5) relaksasi (relaxation) didefinisikan bahwa menggunakan media sosial untuk menghilangkan stres (Palmgreen dan Rayburn, 1979: 6) kegunaan berkomunikasi (communicatory utility) didefinisikan bahwa 


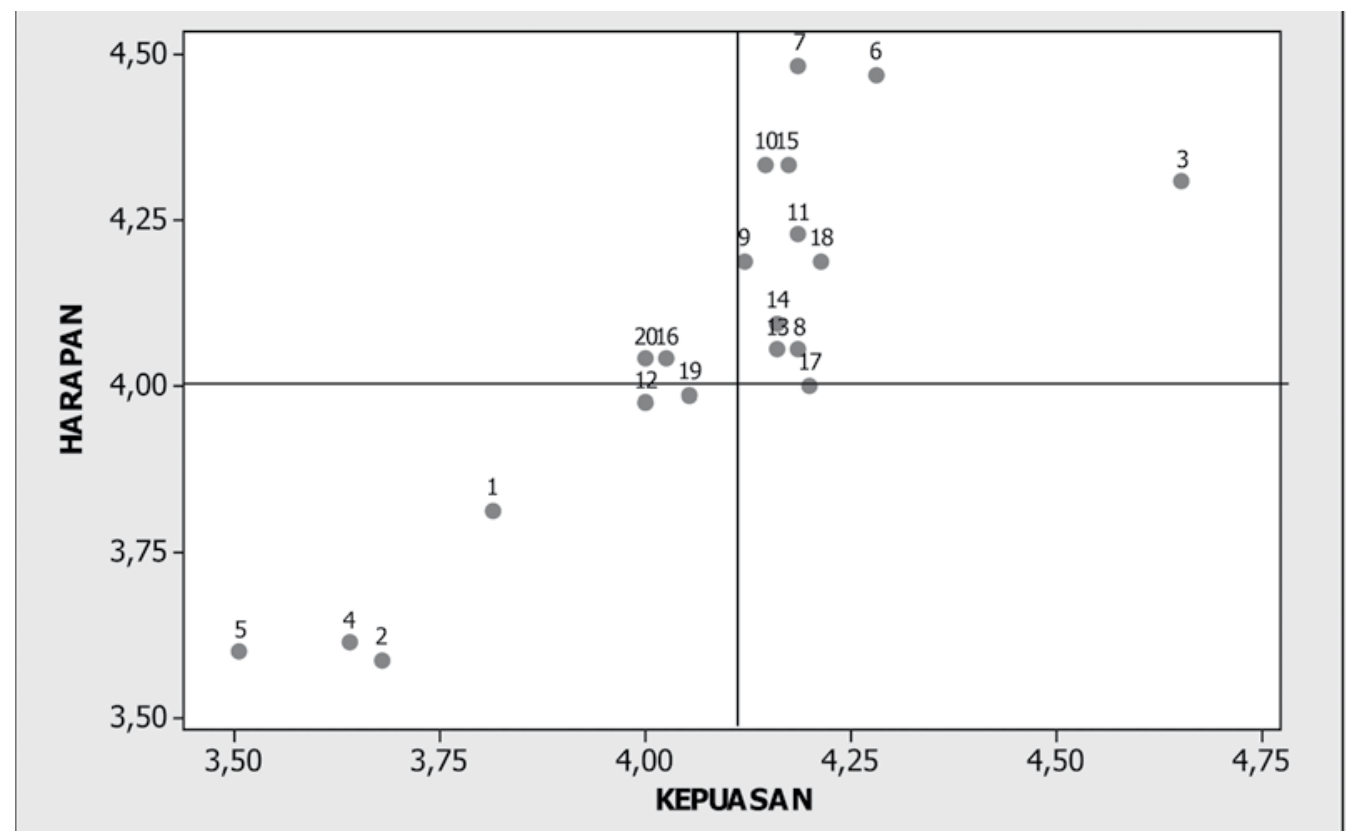

Gambar 3. Pemetaan Diagram Kartesius Importance Performance Analysis Pengguna Media Sosial Instagram pada Mahasiswa

media sosial merupakan fasilitasi komunikasi dan menyediakan informasi untuk berbagi dengan orang lain (Palmgreen dan Rayburn, 1979: dan 7) kenyamanan (convenience utility) didefinisikan bahwa media sosial menyediakan kenyamanan atau kegunaan individu (Papacharissi dan Rubin 2000).

Atribut-atribut kepuasan penggunaan media sosial Instagram dan Path yang digunakan adalah sebagai berikut: 1) Interaksi sosial yang terdiri dari: berinteraksi dengan orang yang memiliki hobi, menemukan sahabat baru, menemukan sahabat lama, bergabung dengan komunitas, berinteraksi dengan artis idola; 2) Mencari informasi yang terdiri dari: mendapatkan informasi dan mendapatkan pengetahuan; 3) Menghabiskan waktu yang terdiri dari: dapat mengisi waktu luang dan dapat menghilangkan kebosanan; 4) Hiburanyang terdiri dari: mendapatkan hiburan dan mendapatkan kesenangan; 5) Relaksasi yang terdiri dari: melepaskan stres dan dapat santai; 6) Kegunaan berkomunikasi yang terdiri dari: bisa berkomunikasi dan dapat berbagi informasi; dan 7) Kenyamanan yang terdiri dari; dapat melakukan promosi produk/jasa, dapat diakses kapan saja, dapat diakses dimana saja, dimudahkan berinteraksi dengan banyak orang dalam waktu bersamaan, dan dapat melakukan transaksi jual beli.

Pada Gambar 3 terlihat bahwa atribut yang menurut pengguna penting pada Instagram namun belum sesuai dengan harapan adalah dapat melakukan promosi produk/jasa dan dapat melakukan transaksi jual beli. Meskipun selama ini Instagram telah memberikan kemudahan pengguna dalam melakukan promosi dan transaksi jual beli, namun fasilitas yang diberikan belum sesuai dengan harapan pengguna. Oleh karena itu, Instagram perlu meningkatkan kenyamanan pengguna dalam promosi produk/jasa dan melakukan transaksi jual beli. Menurut Hermawan (2017: 142) kenyamanan dalam berbelanja secara online merujuk kepada kemudahan dalam menjelajahi atau mencari informasi secara online, yang lebih mudah dibandingkan dengan berbelanja secara tradisional. Survei yang dilakukan APJII (2016) pengguna internet ini mengakui mempunyai berbagai tujuan utama mereka mengakses internet, salah satu diantaranya adalah untuk mencari barang atau melakukan jual beli online, dengan persentasi 63 persen dari total pengguna internet di Indonesia mengaku pernah mengunjungi online shop dan bertransaksi online. Oleh karena itu, Instagram perlu meningkatkan kinerjanya untuk dapat memberikan fasilitas transaksi jual beli 


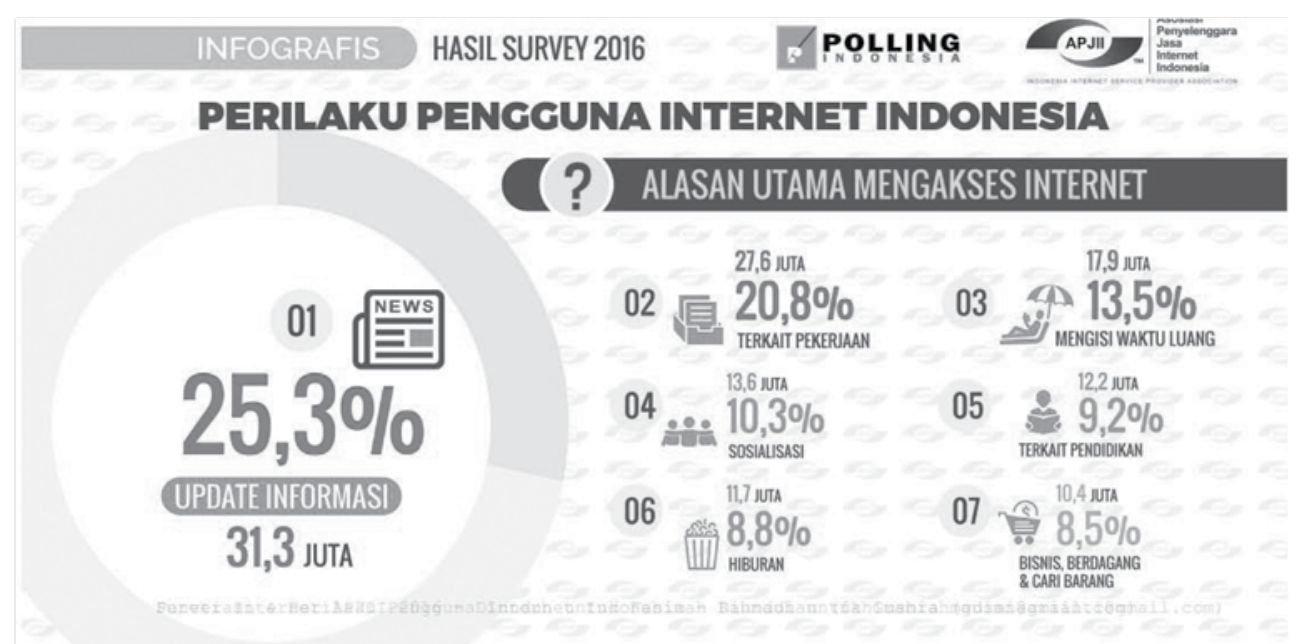

Gambar 4. Alasan utama pengguna mengakses internet

Sumber: Asosiasi Penyelenggara Jasa Internet Indonesia (APJII) 2016

dengan lebih aman dan baik bagi penggunanya.

Menurut mahasiswa atribut yang memiliki kepuasan yang tinggi, atau sesuai dengan kenyataan yang dirasakan oleh pengguna adalah dapat menemukan sahabat lama melalui Instagram, mendapatkan informasi dan pengetahuan, mengisi waktu luang, menghilangkan kebosanan, mendapatkan hiburan dan kesenangan, bersantai, berkomunikasi dan berbagi informasi, dan Instagram dapat diakses kapan saja dan dimana saja. Secara umum motif menggunakan Instagram bagi mahasiswa adalah untuk melakukan interaksi sosial, mencari informasi, mengisi waktu luang, untuk hiburan dan berkomunikasi serta relaksasi dan kenyamanan. Banyak orang menggunakan media sosial untuk melewatkan waktu di tempat kerja atau sekolah. Selain itu, media sosial Instagram memungkinkan penggunanya untuk melakukan interaksi sosial dimana para pengguna dapat berinteraksi langsung dengan media tersebut,

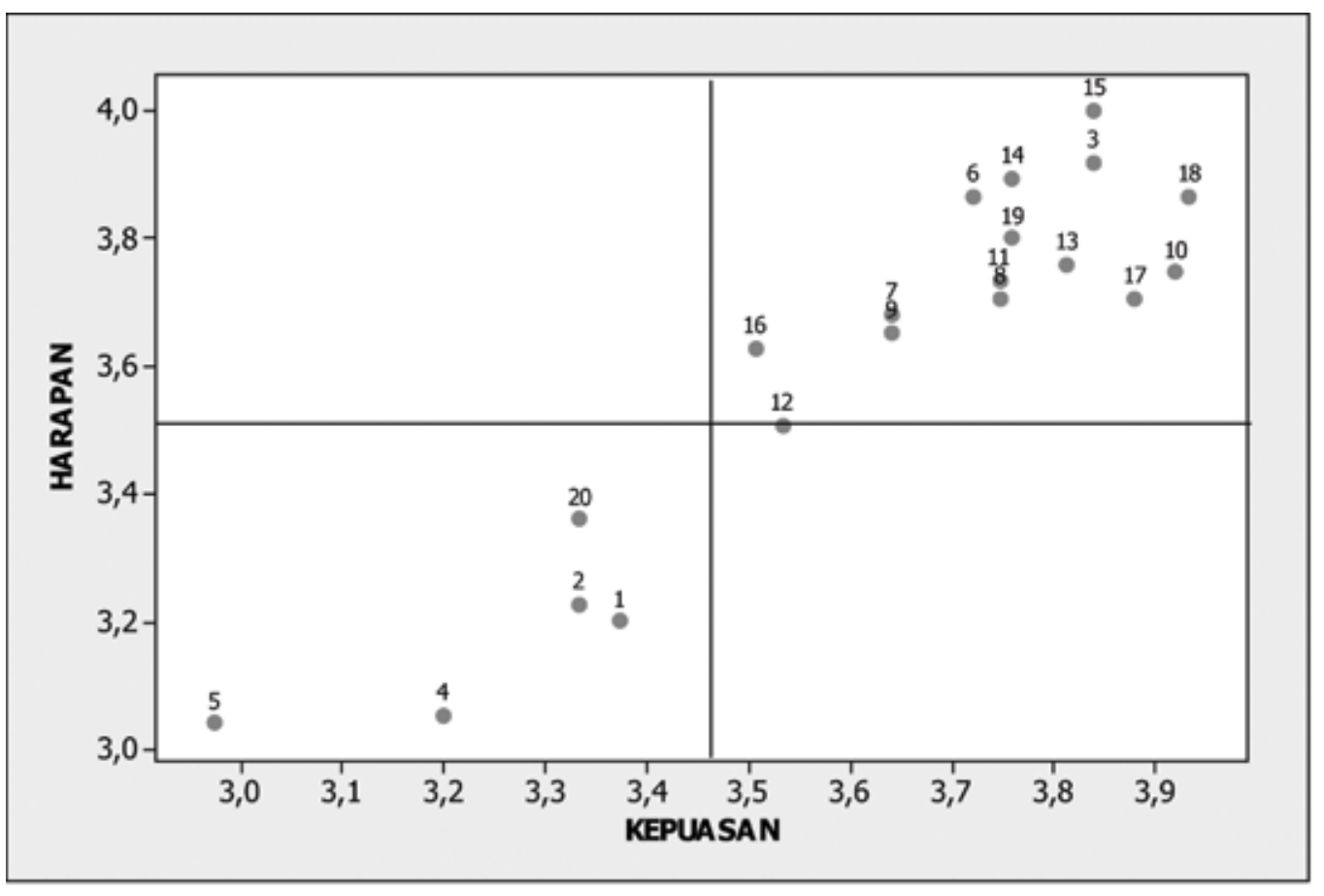

Gambar 5. Pemetaan Diagram Kartesius Importance Performance Analysis Pengguna Media Sosial Path pada Mahasiswa 


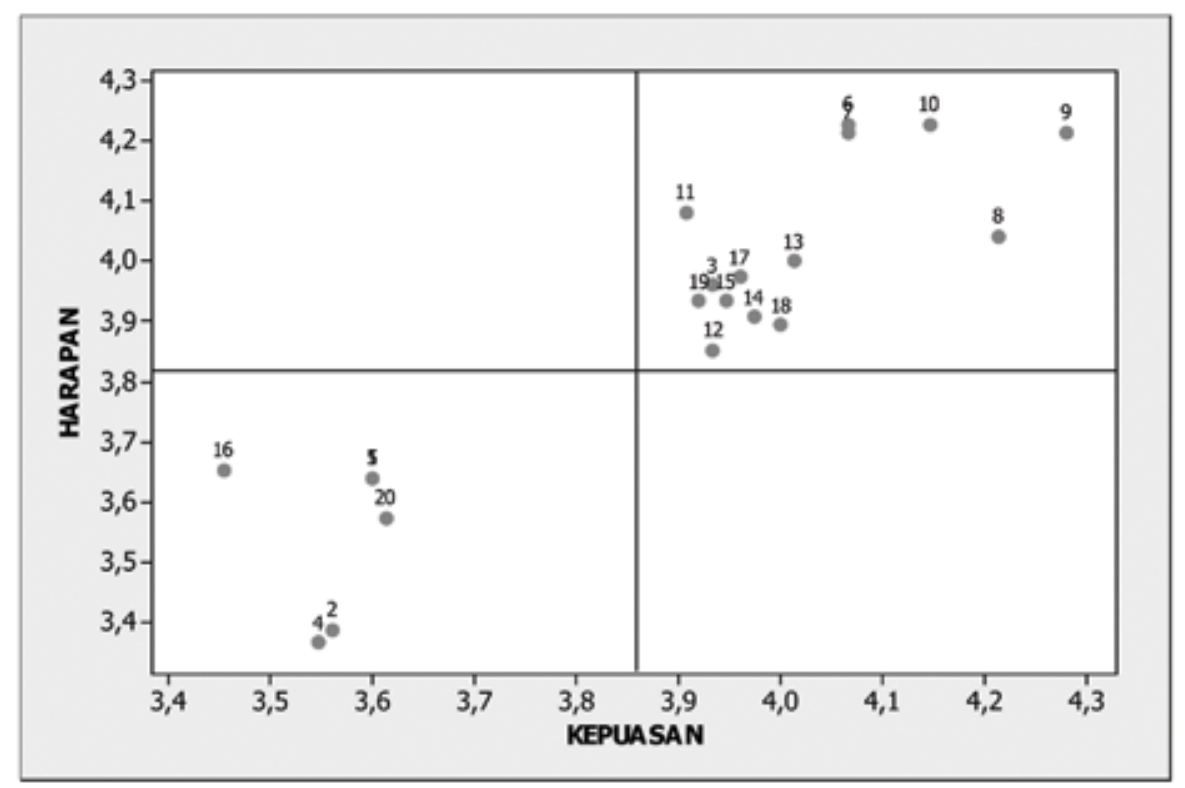

Gambar 6. Pemetaan Diagram Kartesius Importance Performance Analysis Pengguna Media Sosial Instargram pada Siswa SMA

tidak seperti old media, di mana harus terdapat jeda waktu ketika pengguna media ingin menyampaikan sesuatu ke media tersebut. Sehingga dapat dilihat dari teori Uses and Gratifications dimana khalayak dianggap aktif demi memenuhi kebutuhan akan pembicaraan dan berinteraksi sosial.

Menurut survei APJII (2016), alasan utama pengguna mengakses internet adalah untuk mendapatkan informasi, berkaitan dengan pekerjaan, mengisi waktu luang, sosialisasi, terkait pendidikan, hiburan, bisnis berdagang dan mencari barang. (gambar 4).

Bagi mahasiswa atribut yang pengaruhnya yang tidak terlalu besar terhadap kepuasan

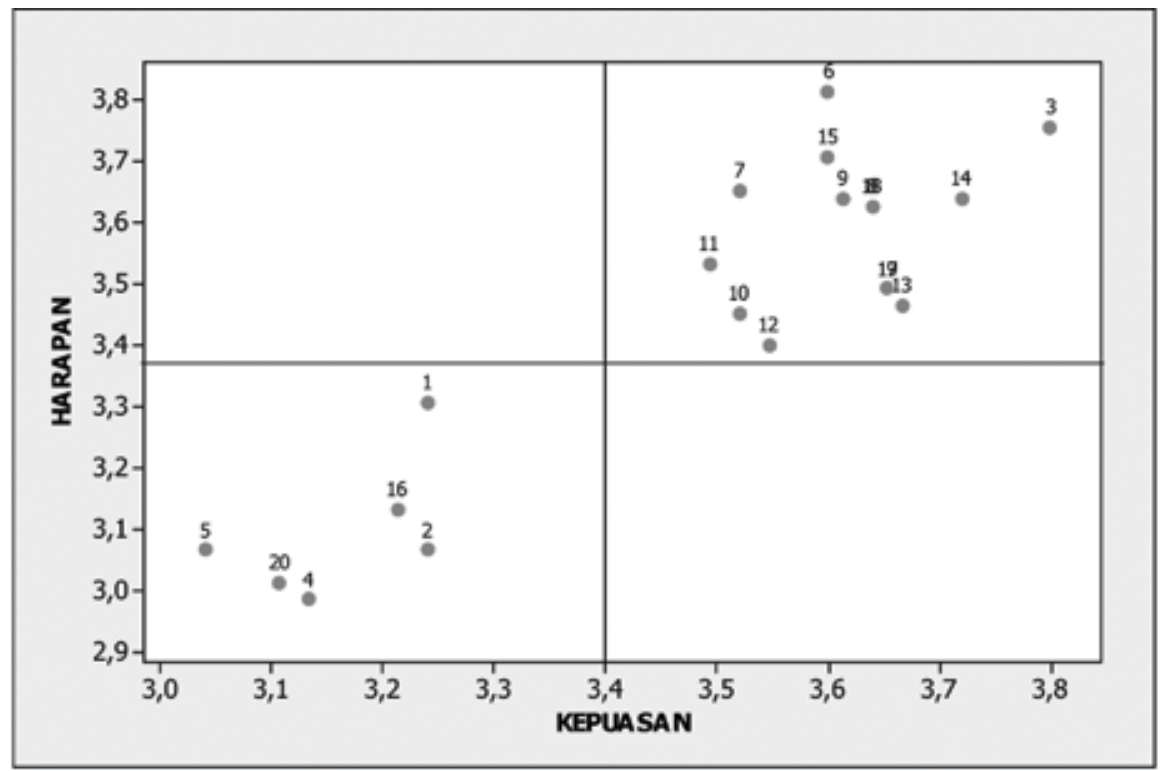

Gambar 7. Pemetaan Diagram Kartesius Importance Performance Analysis Pengguna Media Sosial Path pada Siswa SMA

adalah Instagram memberikan kemudahan dalam berinteraksi dengan orang yang memiliki hobi yang sama, menemukan sahabat baru, bergabung dengan komunitas, berinteraksi dengan artis idola, bisa melepaskan stress dan dimudahkan berinteraksi dengan banyak orang dalam waktu 
bersamaan. Sehingga beberapa atribut tersebut dianggap kurang penting untuk meningkatkan kepuasan pengguna.

Hasil uji kepuasan pengguna media sosial Path menggambarkan bahwa tidak ada atribut yang menjadi prioritas utama yang harus diperbaiki untuk meningkatkan kepuasan pengguna. Mahasiswa beranggapan bahwa atribut dapat berinterkasi dengan orang yang memiliki hobi yang sama, menemukan sabahat baru, bergabung dengan komunitas, berinterkasi dengan artis idola serta melakukan transaksi jual beli merupakan atribut yang kurang berpengaruh terhadap kepuasan pengguna Path. Karena selama ini Path belum digunakan untuk hal-hal tersebut. Jika dibandingkan dengan Instagram, Path jarang digunakan untuk melakukan transaksi jual beli. Path adalah jejaring sosial yang bersifat personal dan menekankan pada kedekatan relasi antara pengguna dan orang-orang yang terhubung dengannya. Menurut Dave Morrin yang juga CEO dari Path berkata: "Yang menjadi visi utama kami adalah untuk membuat sebuah jejaring dengan kualitas yang tinggi dan menjadikan pengguna nyaman untuk berkontribusi setiap waktu."Yang membedakan Path dengan jejaring sosial lainnya adalah dimana hanya pengguna yang telah disetujui yang dapat mengakses halaman Path seseorang. Status privasi dari aplikasi ini menjadikan Path lebih eksklusif dari berbagai jejaring sosial yang ada. Hal ini yang menyebabkan kepuasan pengguna terhadap Path rendah jika dilihat dari kemudahan Path dalam melakukan transaksi jual beli, karena Path memiliki batas maksimal jumlah teman. Limit tersebut dimaksudkan untuk membantu pengguna berbagi pengalaman dan memori bersama orangorang yang benar-benar dekat dengannya.
Siswa SMA beranggapan bahwa atribut menemukan sabahat baru, bergabung dengan komunitas, berinterkasi dengan artis idola, melakukan promosi produk/jasa serta melakukan transaksi jual beli merupakan atribut yang kurang berpengaruh terhadap kepuasan pengguna Instagram. Berbeda dengan pendapat Mahasiswa yang menyatakan bahwa melakukan promosi produk/jasa dan melakukan transaksi jual beli melalui Instagram merupakan hal yang penting. Hal ini berkaitan erat dengan usia mahasiswa yang sudah memasuki dewasa awal, yang lebih produktif dan konsumtif. Menurut Hermawan (2017: 138) niat belanja online lebih tinggi yaitu mahasiswa dengan usia lebih muda dan mahasiswadengan pendapatan besar lebih banyak menghabiskanwaktu untuk berinternet. Sehingga mahasiswa menganggap fasilitas transaksi jual beli dan promosi produk atau jasa merupakan hal yang penting dalam menggunakan media sosial Instagram. Pada Gambar 4, selain dari lima atribut yang masuk pada kuadran III (prioritas rendah), 15 atribut lainnya sudah sesuai dengan harapan pengguna Instagram dikalangan siswa SMA.

Pada Gambar 7, hasil uji kepuasan pengguna media sosial Path menggambarkan bahwa tidak ada atribut yang menjadi prioritas utama yang harus diperbaiki untuk meningkatkan kepuasan pengguna. Kalangan siswa SMA beranggapan bahwa atribut dapat berinterkasi dengan orang yang memiliki hobi yang sama, menemukan sabahat baru, bergabung dengan komunitas, berinterkasi dengan artis idola, melakukan promosi produk/ jasa serta melakukan transaksi jual beli merupakan atribut yang kurang berpengaruh terhadap kepuasan pengguna Path. Terdapat persamaan persepsi antara mahasiswa dan siswa SMA bahwa

Tabel 1 Nilai Customer Satisfaction Index

\begin{tabular}{lcl}
\hline \multicolumn{1}{c}{ Kepuasan } & Indeks Kepuasan & \multicolumn{1}{c}{ Keterangan } \\
\hline Instagram & $78,60 \%$ & Puas \\
Path & $75,88 \%$ & Puas \\
Instagram - Mahasiswa & $82.79 \%$ & Sangat Puas \\
Instagram - Siswa SMA & $79,92 \%$ & Puas \\
Path - Mahasiswa & $74.41 \%$ & Puas \\
Path - Siswa SMA & $71,84 \%$ & Puas \\
\hline
\end{tabular}


Path jarang digunakan untuk berinterkasi dengan orang yang memiliki hobi yang sama, menemukan sabahat baru, bergabung dengan komunitas, berinterkasi dengan artis idola, serta melakukan transaksi jual beli.

\section{Indeks Kepuasan Pengguna Media Sosial Instagram dan Path}

Nilai Customer Satisfaction Index dari atribut Instagram dan Path pada kalangan mahasiswa dan siswa SMA adalah sebagai berikut:

Tingkat kepuasan pengguna media sosial yang paling tinggi adalah pengguna Instagram di kalangan Mahasiswa, dengan indeks kepuasan 82,79 persen. Indeks kepuasan ini menyatakan bahwa pengguna Instagram di kalangan mahasiswa merasa sangat puas dengan fitur dan kelebihan yang dimiliki oleh Instagram. Secara umum, remaja merasa puas dengan menggunakan Instagram dibandingkan dengan Path, dengan indeks kepuasan 78,60 persen. Tingkat kepuasan yang paling rendah adalah kepuasan pengguna Path di kalangan Siswa SMA, dengan indeks kepuasan 71,84 persen. Atribut yang dirasa kurang pengaruhnya untuk meningkatkan kepuasan pengguna media sosial adalah berinterkasi dengan orang yang memiliki hobi yang sama, menemukan sabahat baru, bergabung dengan komunitas, berinterkasi dengan artis idola, serta melakukan transaksi jual beli.

Secara umum, Instagram merupakan media sosial yang paling diminati oleh para remaja jika dibandingkan dengan Path. Menurut Saputro dan Diniati (2017: 61) Instagram menjadi media sosial dengan peningkatan jumlah pengguna aktif terbesar dalam empat tahun terakhir. Jumlah pengguna aktif Instagram melonjak 23 persen dari 130 juta pengguna pada Juni 2013 menjadi 150 juta per bulan pada kuartal keempat tahun lalu.

\section{SIMPULAN}

Faktor-faktor yang mempengaruhi kepuasan pengguna media sosial terdiri dari interaksi sosial (social interaction), mencari informasi (information seeking), menghabiskan waktu (pass time), hiburan (entertainment), relaksasi (relaxation), kegunaan berkomunikasi (communicatory utility) dankenyamanan (convenience utility). Tingkat kepuasan pengguna media sosial yang paling tinggi adalah pengguna Instagram di kalangan Mahasiswa. Tingkat kepuasan yang paling rendah adalah kepuasan pengguna Path di kalangan Siswa SMA. Atribut yang dirasa kurang pengaruhnya untuk meningkatkan kepuasan pengguna media sosial adalah berinterkasi dengan orang yang memiliki hobi yang sama, menemukan sabahat baru, bergabung dengan komunitas, berinterkasi dengan artis idola, serta melakukan transaksi jual beli.

\section{DAFTAR PUSTAKA}

Asosiasi Penyelenggara Jasa Internet Indonesia. 2016. Penetrasi \& Perilaku Pengguna Internet Indonesia Survey 2016. Jakarta: APJII.

Effendi, O. U. 2003. Ilmu -Teori \& Filasafat Komunikasi. Bandung: Citra Aditya Bakti.

Giles, D. 2003. Media Psychology. New Jersey (US): Lawrence Erlbaum Associates, Inc.

Hermawan, Herry. 2017. Sikap Konsumen terhadap Belanja Online. Wacana Jurnal Ilmiah Ilmu Komunikasi, Vol. 16, No. 1, (hal: 136-147).

Innova, E. I. 2016. Motif dan Kepuasan Pengguna Instagram di Komunitas Instameet Indonesia.

Kaplan,A. M, Haenlein M.2010. Users of the world, unite! The challenges and opportunities of social media. Journal Business Horizons, Vol. 53 No. 1.

Kriyantono, R. 2010. Teknis Praktis Riset Komunikasi. Jakarta: Kencana Prenada Media Group.2010.

Littlejhon S. W, Kareen A. F. 2009. Encyclopedia of Communication Theory. United State of America (US): Sage Publications.

Miller, K. 2002. Communication Theories. New York (US): The McGraw-Hill.

Morrisan, Andy C.W., Farit H. U. 2010. Teori 
Komunikasi Massa. Bogor (ID): Ghalia Indonesia.

Rakhmat, J. 1999. Psikologi Komunikasi. Bandung (ID): Remaja Rosdakarya.

Rangkuti, F. 2003. Measuring Customer Satisfaction: Teknik Mengukur dan Strategi meningkatkan kepuasan pelanggan plus analisis kasus PLN-JP. Jakarta: Gramedia Pustaka Utama.

Saputro, D. H, A. Diniati. 2017. Manajemen kesan pengguna media sosial Instagram dalam mengeksistensikan Pancasila. Wacana Jurnal Ilmiah Ilmu Komunikasi, Vol. 16, No. 1, (hal: 57-83).

Siswanta. 2015. Informasi Kesehatan di Media Online. Jurnal Ilmu Komunikasi. Vol. 13 No. 3, (hal: 210-223).

Sugiyono. 2009. Metode Penelitian Bisnis.
Bandung: Alfabeta.

Suliyanto. 2005. Analisis Data dalam Aplikasi Pemasaran. Bogor. Ghalia Indonesia.

Sumarwan, U, Jauzi A, Mulyana A, Karno BN, Mawardi PK dan Nugroho W. 2011. Riset Pemasaran dan Konsumen. Bogor: PT Penerbit IPB Press.

Umar, H. 2004. Metode Penelitian untuk Skripsi dan Tesis Bisnis. Cetakan ke-6. Jakarta: PT Raja Grafindo Persada.

West, R, Lynn HT. 2007. Introducing Communication Theory Analysis and Application. New York (USA): McGrawHil.

h t t p : / / t e k n o.k o m p a s c o m / $\mathrm{read} / 2016 / 10 / 24 / 15064727 / 2016$. pengguna.internet.di.indonesia.capai.132. juta 21-2-2017, diakses pukul 13:24 WIB. 